\title{
Optimization Analysis on the Design Project of Large Diameter Pipe-Roof Engineering
}

\author{
Jianwu Gong ${ }^{\mathrm{a}}$, Bingyan Wen ${ }^{\mathrm{b}}$ and Hao Sheng ${ }^{\mathrm{c}}$ \\ School of Urban Construction, Wuhan University of Science and Technology, Wuhan, Hubei 430065, \\ P.R. China \\ ajwfang@126.com, b1073860647@qq.com, c 467222734@qq.com
}

\begin{abstract}
Keywords: pipe-roof method; design optimization; box culvert; ground settlement; construction Abstract. As a new type of underground engineering reinforcement technology, the pipe-roof method has shown its significant superiority in shallow buried large section tunnel engineering in high traffic urban areas. According to the two design scheme of pipe-roof engineering, the 2-D numerical analysis model has been built to analyze the ground settlement. Results shows that the maximum value of surface settlement with $970 \mathrm{~mm}$ pipes is about $20 \%$ less than that of $800 \mathrm{~mm}$ pipes. The pipe with diameter of $800 \mathrm{~mm}$ has several critical limits during the construction of pipe jacking. The pipe diameter of $970 \mathrm{~mm}$ is the optimal recommended diameter for practical operation in pipe-roof engineering.
\end{abstract}

\section{Introduction}

With the development of economy, the increasing of population and the rapid urban expansion, the traffic is becoming more and more crowded in China. In order to ease the growing traffic pressure, the interchange engineering is more and more popular. As a new type of underground engineering reinforcement technology, the pipe-roof method has shown its significant superiority[1].

The earliest pipe-roof engineering is the passage of Japanese Kawase-Inae crossing railway in 1971[2]. And then several pipe-roof engineering has been built in the following years[3-5]. The first application of pipe-roof method in China is the underground passages in Hong Kong and Taiwan[6,7]. In 2004, a tunnel engineering in Shanghai middle ring line adopted the box culvert jacking method under pipe-roof[8]. In recent years, with the construction of large underground crossing engineering in China, the pipe-roof method has been well applied [9-11].

\section{General Situation of Engineering}

A tunnel project is designed by using the construction technology of pipe-roof method. The width of box culvert in pipe-roof is $23.2 \mathrm{~m}$ and the height is about $8.5 \mathrm{~m}$. According to the requirement of engineering, one design project is that the pipe-roof is made up of 72 steel pipes with the diameter of $800 \mathrm{~mm}$ around the box culvert, and the other project is 60 steel pipes with the diameter of $970 \mathrm{~mm}$. The cross section plans of box culvert in pipe-roof at two design projects are shown in Figure 1.

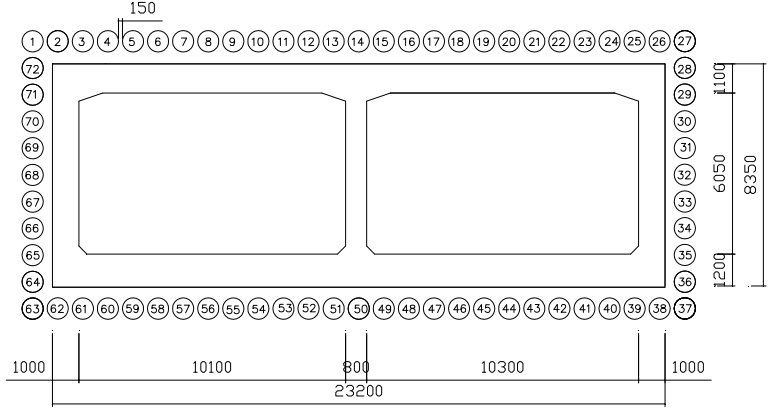

a) pipe diameter of $800 \mathrm{~mm}$

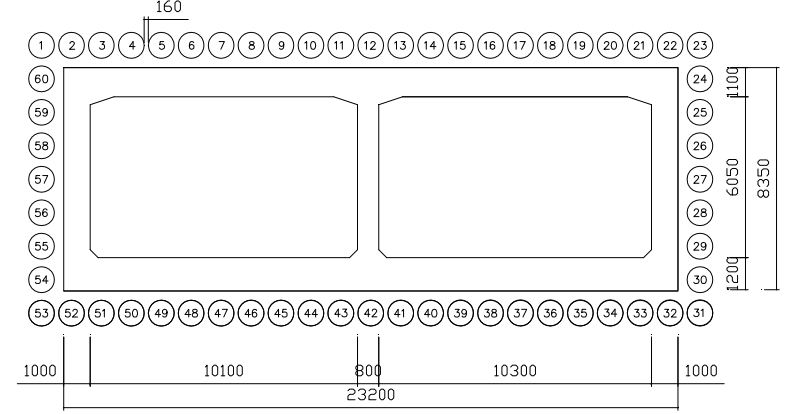

b) pipe diameter of $970 \mathrm{~mm}$

Fig.1. Plan of cross section of box culvert in pipe-roof at two design projects 
In order to determine the optimum project, the numerical analysis model was established for two kinds of design projects, and the simulation and comparison of surface subsidence was carried out during the construction of pipe-roof.

\section{Analysis of Pipe-roof Design}

Analysis Model. The lateral range is $125 \mathrm{~m}$ in the plane numerical simulation model, which is more than 5 times the box culvert span. The top boundary of model is natural earth surface, and the bottom boundary of model is $30 \mathrm{~m}$ below the bottom pipe-roof. The total height of model is about $44 \mathrm{~m}$, which is more than 4 times the box culvert height. The left and right boundary of model is horizontal fixed, bottom boundary is vertical fixed, and top boundary is free. The finite analysis model of box culvert in pipe-roof is shown as Figure 2.

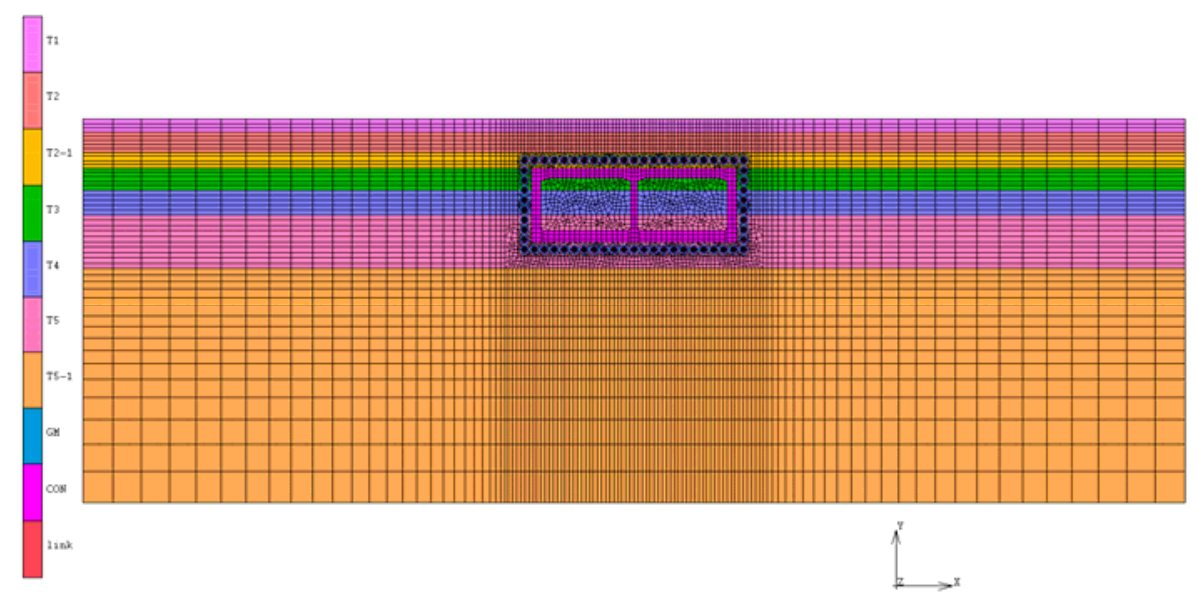

Fig.2. Finite analysis model of box culvert in pipe-roof

Mechanical Parameters. According to the geological condition of pipe-roof engineering, the mechanical parameter of soil from surface to ground is shown in Table 1, and the parameter of steel pipes is shown in Table 2.

Table 1. Physical and mechanical parameters of soil from surface to ground

\begin{tabular}{ccccccc}
\hline Soil layers & $\begin{array}{c}\text { Thickness } \\
{[\mathrm{m}]}\end{array}$ & $\begin{array}{c}\gamma \\
{\left[\mathrm{kN} / \mathrm{m}^{3}\right]}\end{array}$ & $\begin{array}{c}E \\
{[\mathrm{MPa}]}\end{array}$ & $\mu$ & $\begin{array}{c}c \\
{[\mathrm{kPa}]}\end{array}$ & $\begin{array}{c}\varphi \\
{\left[{ }^{\circ}\right]}\end{array}$ \\
\hline Artificial soil & 1.50 & 19.5 & $/$ & $/$ & $/$ & $/$ \\
Mild clay & 2.33 & 19.2 & 23.1 & 0.43 & 28.3 & 11.6 \\
Silt soil & 1.97 & 18.1 & 16.8 & 0.43 & 32.3 & 10.3 \\
Fine sand & 2.27 & 17.1 & 40.0 & 0.43 & 2.0 & 19.0 \\
Silt soil & 2.84 & 19.5 & 20.4 & 0.36 & 18.6 & 14.5 \\
Medium sand & 6.17 & 17.1 & 38.4 & 0.30 & 6.5 & 22.0 \\
Gravel sand & $/$ & 20.4 & 40.2 & 0.36 & 7.0 & 28.0 \\
\hline
\end{tabular}

Table 2. Physical and mechanical parameters of steel pipes

\begin{tabular}{cccccc}
\hline $\begin{array}{c}\text { Diameter } \\
{[\mathrm{mm}]}\end{array}$ & $\begin{array}{c}E \\
{[\mathrm{kPa}]}\end{array}$ & $\mu$ & $\begin{array}{c}\gamma \\
{\left[\mathrm{kN} / \mathrm{m}^{3}\right]}\end{array}$ & $\begin{array}{c}A \\
{\left[\mathrm{~m}^{2}\right]}\end{array}$ & $\begin{array}{c}I \\
{\left[\mathrm{~m}^{4}\right]}\end{array}$ \\
\hline 800 & $2.1 \times 10^{8}$ & 0.3 & 78.0 & 0.039 & 0.00303 \\
970 & $2.1 \times 10^{8}$ & 0.3 & 78.0 & 0.048 & 0.00545 \\
\hline
\end{tabular}


Results and Analysis. According to the simulation analysis, the comparative settlement curves of ground surface caused by the construction of pipe-roof with two kinds of pipe diameter can be drawn as Figure 3.

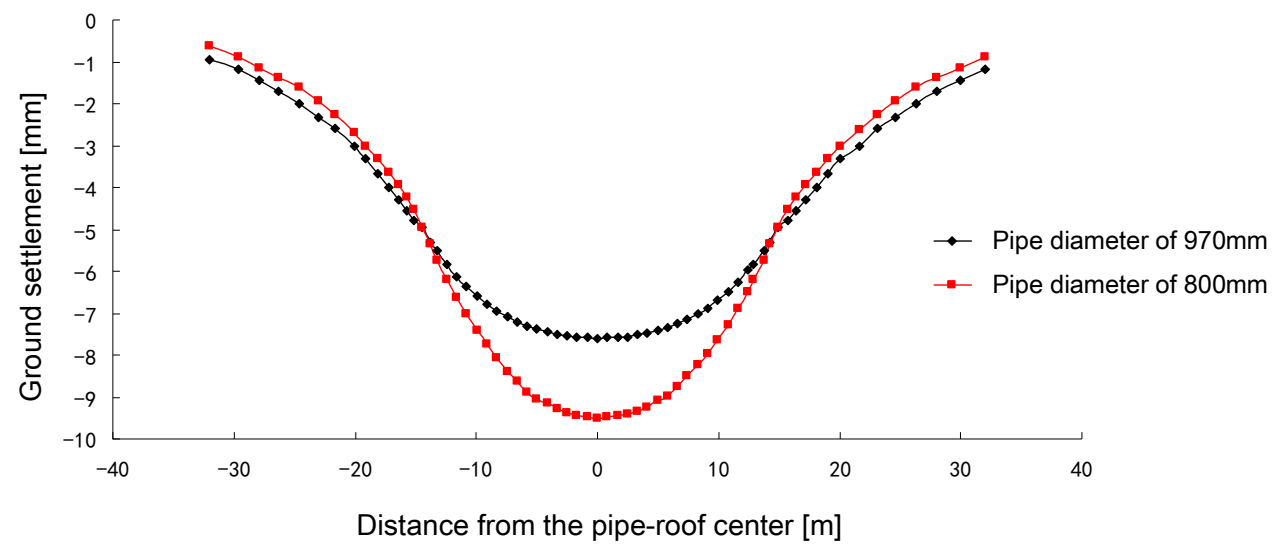

Fig.3. Comparative curves of ground settlement with two kinds of pipe diameter

It can be seen from Fig. 3 that the ground settlement mainly occurs at the middle part of box culvert, and the maximum settlement value caused by construction is about $9.4 \mathrm{~mm}$ when the pipe diameter is $800 \mathrm{~mm}$. The maximum settlement value reduces to $7.6 \mathrm{~mm}$ when the pipe diameter is $970 \mathrm{~mm}$. Though the absolute value difference is small, the relative deformation deduces by about $20 \%$. On the whole, the pipe-roof with diameter of $970 \mathrm{~mm}$ is preferred.

\section{Analysis of Pipe-roof Construction}

From two aspects of construction mechanic and deformation, the pipe-roof technology with the diameter of $800 \mathrm{~mm}$ or $970 \mathrm{~mm}$ can both meet the engineering requirements, and the maximum value of surface settlement is under control. While the $970 \mathrm{~mm}$ pipes are widely applied in the construction of pipe-roof engineering by micro shield technology, and there are several limits for 800mm pipes during the construction of pipe-roof jacking.

Installation of Relay Well. In long distance pipe-roof engineering, the relay well is usually used in the pipe jacking. The clearance diameter is about $490 \mathrm{~mm}$ in the steel relay well with the diameter of $970 \mathrm{~mm}$, and it is barely feasible for engineers to go through. While the clearance diameter is only $320 \mathrm{~mm}$ when the pipe diameter is $800 \mathrm{~mm}$, it is almost impossible to go through. Once the shield machine system fails, engineers can't go in for maintenance, and the construction risk is large.

Construction Efficiency. The cross section size of available spacing in the steel pipes under different diameters is shown in Figure 4. The passage height is only $625 \mathrm{~mm}$ in $800 \mathrm{~mm}$ steel pipe, it is relatively hard for engineer to work long hours in the pipe, so the work efficiency is low and the construction quality is difficult to guarantee. While the passage height increases to $758 \mathrm{~mm}$ in $970 \mathrm{~mm}$ steel pipe, then the work condition is significantly improved, it has tremendous opportunities for the construction quality.

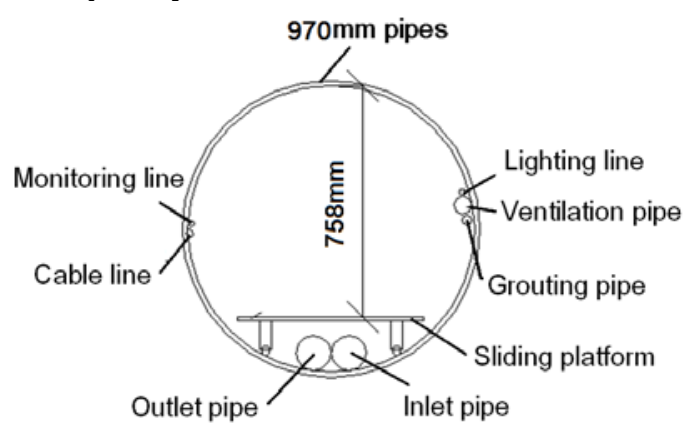

a) pipe diameter of $970 \mathrm{~mm}$

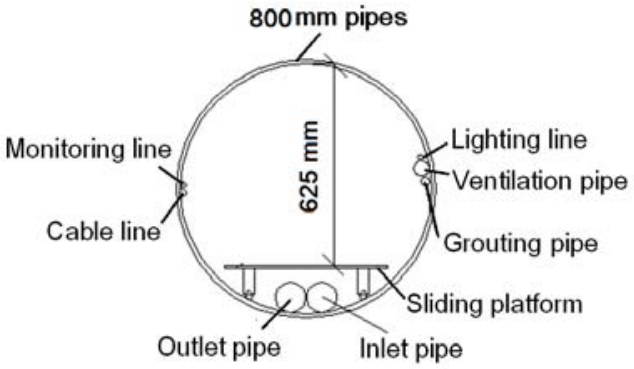

b) pipe diameter of $800 \mathrm{~mm}$

Fig.4. Cross section of available spacing in pipes under different diameters 


\section{Conclusions}

Based on a pipe-roof engineering, the 2-D numerical analysis model has been built. Through the contrast of ground settlement and the analysis of construction feasibility with different pipe diameter, the following conclusions can be drawn.

The pipe-roof technology with the diameter of $800 \mathrm{~mm}$ or $970 \mathrm{~mm}$ can both meet the engineering requirements, and the maximum value of surface settlement with $970 \mathrm{~mm}$ pipes deduces by about $20 \%$ than that of $800 \mathrm{~mm}$ pipes. So, the pipe-roof with diameter of $970 \mathrm{~mm}$ is preferred.

From the aspect of construction feasibility, the pipe-roof with diameter of $970 \mathrm{~mm}$ also has comparative advantage for that there are several construction limits for $800 \mathrm{~mm}$ pipes during the pipe jacking. Considering that the larger diameter pipe jacking machine, the greater the effect of disturbance on the surrounding ground, the pipe diameter of $970 \mathrm{~mm}$ is the optimal recommended diameter for practical operation in pipe-roof engineering.

\section{Acknowledgements}

This work was financially supported by National Natural Science Foundation of China (51208395).

\section{References}

[1] B.Q. Yu and C.C. Chen: Technology of Pipe Jacking Construction. (China Communications Press, China 1998). (in Chinese)

[2] P.J. Coller and D.G. Abbott, In: High Level Radioactive Waste Management, volume 2 of Proceedings of the Annual International Conference, Las Vegas, NV(1994)

[3] G. Musso: Civil Engineering, Vol.11(1979), p.79

[4] D.G. Abbott: Civil Engineering, Vol.73(2003), p.46

[5] D. Peter: Tunnels and Tunneling, Vol.23(1993), p.19

[6] G.Y. Xiong: Journal of Fuzhou University, Vol.25(1997), p.56 (in Chinese)

[7] H.J. Liao: Geotechnical Engineering, Vol.119(1996), p.202

[8] J.K. Ge: Shanghai Highways, No.1(2004), p.38 (in Chinese)

[9] Y.Q. Qu: Haihe Water Resources, No.5(2012),p.52 (in Chinese)

[10] Z.H. Li and J. Li: Modern Tunnelling Technology, Vol.52(2015),p.63 (in Chinese)

[11] J.L. Feng: Tunnel Construction, Vol.35(2015),p.473 (in Chinese) 